\title{
Francesco Fiorentino, Il teatro francese del Seicento
}

\section{Monica Pavesio}

\section{OpenEdition}

\section{Journals}

\section{Edizione digitale}

URL: http://journals.openedition.org/studifrancesi/7899

DOI: 10.4000/studifrancesi.7899

ISSN: 2421-5856

\section{Editore}

Rosenberg \& Sellier

\section{Edizione cartacea}

Data di pubblicazione: 1 juillet 2009

Paginazione: 388

ISSN: 0039-2944

\section{Notizia bibliografica digitale}

Monica Pavesio, «Francesco Fiorentino, // teatro francese del Seicento», Studi Francesi [Online], 158 (LIII ] II) | 2009, online dal 30 novembre 2015, consultato il 10 janvier 2021. URL: http://

journals.openedition.org/studifrancesi/7899; DOI: https://doi.org/10.4000/studifrancesi.7899

Questo documento è stato generato automaticamente il 10 janvier 2021.

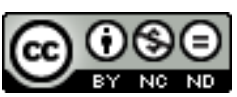

Studi Francesi è distribuita con Licenza Creative Commons Attribuzione - Non commerciale - Non opere derivate 4.0 Internazionale. 


\title{
Francesco Fiorentino, Il teatro francese del Seicento
}

\author{
Monica Pavesio
}

\section{NOTIZIA}

FRANCESCO FIORENTINO, Il teatro francese del Seicento, Bari, Laterza, 2008, Manuali Laterza, Istituzioni di letteratura francese, pp. 142.

1 Il manuale sul teatro francese secentesco, il primo della serie Istituzioni di letteratura francese diretta dallo stesso Fiorentino, è suddiviso in sei capitoli. Il primo funge da introduzione, presentando le sale teatrali e le compagnie francesi secentesche ed illustrando le tecniche di recitazione ed i difficili rapporti fra teatro e chiesa nella Francia del XVII secolo. Seguono poi una serie di capitoli che ripercorrono cronologicamente lo sviluppo e l'affermazione della pratica teatrale, partendo dalle troupes itineranti per arrivare al successo dell'opéra alla fine del secolo.

2 L'A. indaga i grandi classici del teatro francese in una prospettiva che unisce l'attenzione per il testo a quella per la messa in scena. Riferimenti bibliografici precisi, suddivisi in più sezioni, una ricca tavola cronologica degli avvenimenti storici, teatrali, letterari, artistici e culturali ed un dettagliato indice dei nomi concludono questo utile manuale che ha il pregio di contenere in poco più di cento pagine il ricco e complesso panorama teatrale francese secentesco. 